\title{
Diversity management in organizations - the measuring of the benefits: Visegrad Group (V4) countries perspective
}

Elwira Gross-Gołacka

Faculty of Management

University of Warsaw, Poland

egross@wz.uw.edu.pl

Marta Kusterka-Jefmańska

Faculty of Management

Wroclaw University of

Economics and Business, Poland

marta.kusterka@ue.wroc.pl
Teresa Kupczyk

Department of Management

General Tadeusz Kościuszko

Military University of Land

Forces, Poland

teresa.kupczyk@awl.edu.pl

Bartłomiej Jefmański

Faculty of Economics and

Finance

\author{
Wroclaw University of \\ Economics and Business, Poland \\ bartlomiej.jefmanski@ue.wroc.pl \\ Izabela Warwas \\ Faculty of Economics and \\ Sociology \\ University of Lodz, Poland \\ izabela.warwas@uni.lodz.pl
}

\begin{abstract}
Popularization of the diversity management concept and its practical implementation at the level of organizations requires becoming organization owners aware of potential benefits. Therefore, the article presents the survey results of the organization representatives on the benefits of implementing the diversity management concept. The analytical part of the article is based on the survey results of 401 representatives of the organizations located in the Visegrad Group countries. The managing diversity concept knowledge and awareness of the resulting benefits were analyzed at the level of the whole group as well as in the cross-section of the member countries. In the analytical part of the article, selected modified multi-criteria decision making methods for ordinal data were used. Adopting the analytical approach also allowed to indicate the most important benefits that, in the opinion of the organization representatives, are the consequence of the diversity management concept implementation.
\end{abstract}

\section{Introduction}

Diversity have been prevalent in the management literature since the 1980s. Today, it should be assumed that the inner and outer surroundings of an organisation elicit the organisation's activity, which ought to reflect the changes taking place on the global (or local) and competition market.
It therefore seems that the success and competitiveness of an organisation depends on its ability to implement and accept diversity and realise what benefits stem from it [13, 23, 24, 27, 50, 53]. The thesis formulated in this way allows us to believe that today no entity can afford to ignore the aspect of the diversity of customers, suppliers, shareholders and employees if they want to build their competitive advantage.

An overview of literature allows one to observe that diversity management is an interdisciplinary category, which utilises several perspectives, namely economics, social and biological ones. In the literature, diversity have been seen as the learning orientation of an inclusive policy $[28,29]$ and equal opportunity policy [33].

However, much of the literature written show that the basic concept of managing diversity accepts that the workforce consist of a diverse population of people. It is founded on the premise that harnessing these differences will create a productive environment in which everybody feels valued, where their talent are being fully utilised and which organizational goals are met [21]. Finally, managing diversity is presented not only as redressing the balance also as an attempt to change of the culture of organizations, meeting one of the major criticism of the dominant liberal equality approach [26].

Much less research has looked at how companies can contribute to the create and effective manage of diverse workforce. Especially in Middle part of Europe. This gap exists even though considerable work on diversity management has identified the impact and benefits form that. Therefore, our research question is: 
what knowledge about the benefits of managing diversity do managers Visegrad Group (V4) countries?

The main goal of the paper is to identify and prioritize the main benefits brought by diversity management from the perspective of building competitive advantages to organizations located on the territory of Visegrad Group (V4) countries (Poland, Czech Republic, Slovakia, Hungary).

For this purpose, a study has been conducted among representatives of organizations located on the territory of the V4 group countries. The awareness of the potential benefits stemming from the concept of diversity management has both educational and promotional values. It is an important element of knowledge that organizations can manage to build their competitive advantage.

The rest of this paper will start with a review of related literature, followed by goals of research. Next the paper describes its research method and reports of research results. Last the paper gives discussion and conclusion.

\section{Literature review}

\subsection{Diversity and management diversity}

Diversity, in its broad definition, can relate to any perceived difference and similarity between people, both observable and otherwise (the effect will be a wide and universal approach). Diversity is understood as a collection of characteristics, including all characteristics differentiating one person from another (in terms of employees) and their similarities [2, 4, 21, 22, 26, 32, 35, 38, 43, 51, 52, 53, 54].

Diversity management is a wide and complex term, and therefore it seems that it is difficult to set a single standard or system encompassing all aspects associated with the issue. Authors in multiple publications define the field and its components in different ways [26, 39, 53]. An overview of them allows one to observe that diversity management is an interdisciplinary category, which utilises several perspectives, namely economics, social and biological ones.

M. Özbilgin \& A. Tatli [41] defines diversity management as a management philosophy, meaning that diversity in organisations is recognised and valued, and that the goal is to increase the performance of the organisation. Egan and Bendick [7] define diversity management as a systematic and planned creation of programmes and procedures, aimed at improving the interaction between different (based on ethnic origin, gender and culture) employees in order to make diversity a source of creativity, complementarity and higher effectiveness of an organisation (...)". Generally, diversity management regards utilising all available talents in an organisation, without referring to ethnocentrism and stereotypes [15]. It regards to a group of employees: conducting policy on behalf of diversity, while contributing to an increase of innovativeness and creative activities, reducing any lacks of human resources with specified abilities and improving the quality of service for clients. It approach through strategic management oriented towards adapting the organisation to its environment $[30,38]$.

\subsection{Knowledge about diversity management in organizations}

A review of the literature on the subject and the experiences of practitioners shows that the implementation of the concept of diversity management brings a number of benefits. As pointed out by Pocztowski [42], a crucial role in the context of diversity among human resources is played by building a leadership sensitive to cultural differences (and not only), one that is able to focus employees coming from different cultural circles and having different preferences in terms of leadership behaviour.

However, the literature on workplace diversity suggests that diversity contributes not only to organizational outcomes such as performance, creativity, and innovation $[1,6,37]$ but also to group and individual benefits $[10,46]$. Individuals can enhance their expertise by harnessing the experience of other group members.

Also review of the literature on the topic and experience of practitioners allows one to observe that the implementation of the concept of diversity management ensures the ability to improve the operational results of an organisation the short and medium -term perspective as well as strategic assets of the company in the long-run.

Investments made towards managing diversity contribute to creating and reinforcing human and organisational capital, which today is an important element influencing effectiveness. It therefore seems that diversity in an organisation carries many benefits, including those in a macroeconomic perspective which contributes to increasing efficiency, increasing innovativeness and creative activities, or gaining new markets and maintaining current ones. Whereas the improvement of goods and services for the benefit of the clients, at-tracts talents from the widest possible group of potential employees, reduces any lacks of human resources and limits fluctuations of employees - these are all benefits from a micro-economic perspective [49]. On the other hand, one potential 
advantage associated with diversity concerns cost savings. Cost savings, in this instance, focus on the negative impact the mismanagement of diversity has on an organisation's bottom line. This negative impact specifically refers to higher staff turnover costs, higher absenteeism rates and lawsuits on sexual, age and race discrimination. Regarding higher turnover costs, turnover among diverse employees is a costly and significant problem for many organisations, as are the subsequent added recruiting, staffing and training costs per person. Additionally, a persistent flow of employees through an organisation results in employees continually climbing the learning curve, rather than performing to their full potential $[11,12$, $31,44,55]$. It is arguable, therefore, that managing diversity enables employees to perform to their potential $[25,40]$.

The benefits outlined above can be measured quantitively and their relationship with investments in diversity management policy can be established. However, this relationship only remains partial. At the same time, there is a lack of transparency with regards to the employed indicators used in research, as both in managing human resources and in managing diversity, it is difficult to indicate a direct and singular dependency of the activities on the financial profit of the firm [6, 26, 34, 37].

According to the author, it seems that the character and reach of the undertaken activities in organisations can depend on the size, scope and character the company's activities. Organisations employ diversity management policies for more than one of the aforementioned reasons, which interact with each other and are considered collectively and reflect strong impulses to meaningful internal changes within an organisation. But the relative importance of each of these reasons has changed also depending on the organisation and its characteristics [35, 51].

Maximising and tapping into diversity in the workplace is an important issue for the quality of managing human resources (and not only) today [16]. This new way of thinking about diversity focuses on meeting the needs of the individual and not so much on an HR-centered initiative. Today, it is not only about having diversity within a company but leveraging that diversity to produce better products and services [56].

\section{Materials and methods}

\subsection{Multi-criteria decision making methods in analysis of socio-economic phenomena}

Multi-criteria decision making can be defined as a complex process of selecting the best possible alternative characterized by many criteria. Many methods have been proposed in solving this problem and their taxonomy has been presented, among others, in the study of Hwang and Yoon [18]. Multi-criteria decision making methods (MCDM) are used in many areas, such as: supply chain management and logistics, design, engineering and manufacturing systems, business and marketing management, health, safety and environment management, human resources management, energy management, chemical engineering, water resources management [14, 58]. Within the specified application areas, MCDM methods are often used to identify and prioritize determinants of selected socio-economic phenomena.

An important group of MCDM methods are methods that use appropriate distances of the assessed alternatives from the ideal solution. A pioneering solution in this area was the Hellwig's method [17] which in the literature is interchangeably referred to as: synthetic development measure, Hellwig's development measure, Hellwig's pattern of development, Wrocław Taxonomic Method, Hellwig's synthetic measure. In this article, this method will be referred to as Hellwig's synthetic measure (HSM). The TOPSIS (Technique for Order Preference by Similarity to an Ideal Solution) method proposed by Hwang and Yoon [18] is an extension of the HSM method. The methods are very similar and the main difference is in the method of calculating the synthetic measure. The advantage of using these methods is that the results are easy and intuitive to interpret. The methods used make it possible to calculate the value of the synthetic measure for each of the benefits, which facilitates the construction of the ranking of the importance of the analyzed benefits. On the other hand, the results obtained using these methods may be sensitive to how weights for variables and coordinates of ideal and negative-ideal solutions are determined.

\subsection{HSM and TOPSIS methods based on generalised distance measure}

There are two main approaches to solving multicriteria problems described by ordinal variables using the HSM and TOPSIS methods. The first one is based on the so-called artificial amplification of the measurement scale and treatment of the measurement results as from the ratio scale and the use of the classic HSM and TOPSIS methods based on the euclidean distance. However, this is a controversial approach, since the ordinal measurement scale allows only the relations of equality, diversity, minority and majority on its values. In addition, it assumes that the distances 
between the points of these scales are the same, but these distances are not known at all. The second, alternative approach is to use the fuzzy HSM and TOPSIS methods, which does not assume equal distances between the points of the measurement scales. However, the method of determining the parameters of fuzzy numbers is usually subjective, which can affect the reliability of the results obtained by the HSM and TOPSIS methods [20]. The solution may be to combine the HSM and TOPSIS methods with the generalized distance measure for ordinal scales (GDM2), proposed by Walesiak [57], which uses acceptable relations for ordinal scales. It is a context distance measure, which is based on an information about relations in which objects comparable to other objects from a given data set remain.

The GDM2 measure is standardized in the range $[0 ; 1]$. The value of 0 means that for the compared objects, only equality relations occur between the corresponding observations on the variables. Value 1 means that for comparable objects, only majority (minority) or majority (minority) relations and equality relations take place between corresponding observations on variables, if these relations are maintained in relation to other objects (i.e. objects with numbers $l=1, \ldots, n$ where $l \neq i, k)$.

\subsection{GDM2-HSM and GDM2-TOPSIS methods}

$A=\left\{A_{i} \mid i=1, \ldots, n\right\}$ has been characterized through a set of decision criteria $C=\left\{C_{j} \mid j=1, \ldots, m\right\}$. The evaluation of the criteria was expressed on an ordinal scale (e.g. with the use of verbal categories). Establishing a ranking of alternatives in terms of the adopted decision criteria using the GDM2-HSM methodology requires the following steps:

Step 1. Construction of a decision matrix containing an evaluation of alternatives according to the adopted decision criteria.

Step 2. Identification of benefit and cost criteria in the set of decision-making criteria.

In case of criteria evaluation on the ordinal measurement scales there is no need, as in the case of metric (interval and/or quotient) scales, to use standardization. It is only necessary to establish in a set of criteria the benefit and cost criteria and then, for each of them, to establish the order of individual values of the ordinal scale.

Step 3. Determining the coordinates of an ideal $A^{+}$ and negative-ideal $A^{-}$solution.
Step 4. (optional) Determination of the weighting system for decision criteria. The application of the GDM2 distance measure with differentiated weights requires that the decision criteria weights meet the following assumptions: $w_{j} \in[0 ; 1], \sum_{j=1}^{m} w_{j}=1$ or $w_{j} \in[0 ; m], \sum_{j=1}^{m} w_{j}=m$.

Step 5. Calculation for each alternative GDM2 distance from the ideal solution $A^{+}$according to formula (1).

Step 6. Determination of the synthetic measure for each alternative:

$$
S_{i}^{G D M 2-H S M}=1-\frac{d_{i A^{+}}}{d_{0}},
$$

where: $d_{i A^{+}}$- GDM2 distance of the i-th alternative from an ideal solution $A^{+}, d_{0}=\bar{d}_{0}+2 s\left(d_{0}\right)$, $\bar{d}_{0}=\frac{1}{n} \sum_{i=1}^{n} d_{i 0}, s\left(d_{0}\right)=\left[\frac{1}{n} \sum_{i=1}^{n}\left(d_{i 0}-\bar{d}_{0}\right)^{2}\right]^{\frac{1}{2}}$.

The measure takes values from the interval $[0 ; 1]$. The closer the measure values to one, the i-th alternative closer to the ideal solution $A^{+}$.

Step 7. Determination of the ranking of alternatives on the basis of decreasing measurement values $S_{i}^{G D M 2-H S M}$

The difference between GDM2-HSM and GDM2TOPSIS is steps 5-6. In the step 5 of the GDM2TOPSIS method, the distances of each alternative from both ideal and negative-ideal solutions are calculated. The calculation of the synthetic measure (relative closeness measure) in the step 6 is also different. It is computed for each alternative according to the formula:

$$
S_{i}^{G D M 2-T O P S I S}=\frac{d_{i A^{+}}}{d_{i A^{+}}+d_{i A^{-}}},
$$

where: $d_{i A^{+}}$- GDM2 distance of the i-th alternative from an ideal solution $A^{+}, d_{i A^{-}}-$GDM2 distance of the $\mathrm{i}$-th alternative from negative-ideal solution $A^{-}$.

The measure takes values from the interval $[0 ; 1]$. The ranking of alternatives is based on decreasing values of a $S_{i}^{G D M 2-T O P S I S}$.

\section{Results}

The aim of the analysis was to identify and prioritize the benefits of diversity management in 
organizations. The analysis uses the opinions of the organization's representatives (mainly owners and HR specialists) located in the Visegrad Group. Opinions were collected as a part of a wider survey entitled „Diversity management in the V4 countries as an answer for demographic changes" and completed in 2017. The survey was supported by the International Visegrad Fund. The size of the research sample was equal to 401 organizations. In each of the countries of the Visegrad Group, 100 interviews were conducted, except for the Czech Republic, where 101 representatives of the organizations participated in the survey. The survey was mainly attended by the owners and representatives of small and medium-sized private enterprises (nearly 70\%).

The literature on the subject provides a lot of research and scientific considerations that confirm the impact of diversity management on the functioning of the company $[1,3,6,15,26,34,35,37,38,51]$. The analysis of this area allowed for the definition of potential key benefits that can be brought by the organization by managing diversity, as shown in Table 1.

\section{Table 1. Potential benefits for organizations from the diversity management}

\begin{tabular}{cc}
\hline No. & Benefit \\
\hline B1 & $\begin{array}{c}\text { Improvement of organization image and reputation } \\
\text { Better motivation and productivity of employees / } \\
\text { B2 }\end{array}$ \\
B3 & $\begin{array}{c}\text { Higher level of employee satisfaction } \\
\text { B4 }\end{array}$ \\
B5 & $\begin{array}{c}\text { Ancrease in enterprise profits } \\
\text { B6 to new markets and acquiring new } \\
\text { customers }\end{array}$ \\
B7 & $\begin{array}{c}\text { Maintaining the most talented employees in an } \\
\text { organization / limiting employee retention }\end{array}$ \\
B8 & $\begin{array}{c}\text { Increased creativity and innovation through } \\
\text { building diverse teams }\end{array}$ \\
B9 & $\begin{array}{c}\text { Reducing risk of discrimination in an organization } \\
\text { / avoiding lawsuits }\end{array}$ \\
B10 & $\begin{array}{c}\text { Increased customer loyalty / retention of existing } \\
\text { clients }\end{array}$ \\
B11 & $\begin{array}{c}\text { Cost reduction (acquisition, training, employment, } \\
\text { employee replacements) }\end{array}$ \\
\hline
\end{tabular}

In the measurement of the opinion on the benefits from the diversity management, a 5-point measurement scale was used (where: 1 - „diversity management contributes the least to organization achieving the specified benefit" and 5 - "diversity management contributes the most to organization achieving the specified benefit). The GDM2-TOPSIS method was used to determine the hierarchy of the importance of the benefits. The choice of the method was dictated by the measurement instrument used in the form of an electronic questionnaire and ordinal measurement scale for the benefits assessments.

The ranking of the importance of diversity management benefits using the GDM2-TOPSIS method has been developed for each of the four countries of the Visegrad Group. For the purposes of this analysis, it was assumed that each of the potential benefits is an alternative assessed and the opinions of an organization representative are the decision criteria. The same weights were adopted for each of the decision criteria. It was found that all decision criteria were benefit criteria. The values of all the coordinates of the ideal solution were assumed at level 5, i.e. the maximum value of the adopted ordinal scale. All coordinates of the anti-ideal solution were set at level 1. The rankings of the benefits and values of the relative closeness measure to the ideal solution (4) were presented for each of the four countries of the Visegrad Group (Tables 2-5).

Table 2. Ranking of benefits from diversity management in enterprises in Poland

\begin{tabular}{ccccc}
\hline Benefit & $\begin{array}{c}\text { GDM2- } \\
\text { HSM }\end{array}$ & Rank & $\begin{array}{c}\text { GDM2- } \\
\text { TOPSIS }\end{array}$ & Rank \\
\hline B1 & 0.2943 & 6 & 0.5536 & 6 \\
B2 & 0.2118 & 8 & 0.5130 & 8 \\
B3 & 0.2798 & 7 & 0.5504 & 7 \\
B4 & 0.1287 & 9 & 0.4481 & 9 \\
B5 & 0.3677 & 3 & 0.6006 & 3 \\
B6 & 0.3879 & 2 & 0.6215 & 2 \\
B7 & 0.2960 & 5 & 0.5646 & 5 \\
B8 & 0.5170 & 1 & 0.6986 & 1 \\
B9 & 0.3073 & 4 & 0.5692 & 4 \\
B10 & 0.0804 & 10 & 0.4343 & 10 \\
B11 & 0.0514 & 11 & 0.4128 & 11 \\
\hline
\end{tabular}

Table 3. Ranking of benefits from diversity management in enterprises in Czech Republic

\begin{tabular}{ccccc}
\hline Benefit & $\begin{array}{c}\text { GDM2- } \\
\text { HSM }\end{array}$ & Rank & $\begin{array}{c}\text { GDM2- } \\
\text { TOPSIS }\end{array}$ & Rank \\
\hline B1 & 0.1834 & 8 & 0.4485 & 8 \\
B2 & 0.2309 & 6 & 0.4841 & 6 \\
B3 & 0.3094 & 4 & 0.5314 & 4 \\
B4 & 0.1997 & 7 & 0.4574 & 7 \\
B5 & 0.1682 & 9 & 0.4344 & 9 \\
B6 & 0.2599 & 5 & 0.4954 & 5 \\
B7 & 0.3403 & 3 & 0.5512 & 3
\end{tabular}




\begin{tabular}{ccccc} 
B8 & 0.3882 & 2 & 0.5843 & 2 \\
B9 & 0.4702 & 1 & 0.6385 & 1 \\
B10 & 0.1227 & 10 & 0.3976 & 10 \\
B11 & 0.0155 & 11 & 0.3239 & 11 \\
\hline
\end{tabular}

Table 4. Ranking of benefits from diversity management in enterprises in Slovakia

\begin{tabular}{ccccc}
\hline Benefit & $\begin{array}{c}\text { GDM2- } \\
\text { HSM }\end{array}$ & Rank & $\begin{array}{c}\text { GDM2- } \\
\text { TOPSIS }\end{array}$ & Rank \\
\hline B1 & 0.2907 & 7 & 0.4595 & 7 \\
B2 & 0.4595 & 3 & 0.5952 & 3 \\
B3 & 0.3282 & 6 & 0.4928 & 6 \\
B4 & 0.2421 & 8 & 0.4351 & 8 \\
B5 & 0.2289 & 9 & 0.4225 & 9 \\
B6 & 0.3448 & 5 & 0.5145 & 5 \\
B7 & 0.4019 & 4 & 0.5596 & 4 \\
B8 & 0.5781 & 2 & 0.6789 & 2 \\
B9 & 0.5972 & 1 & 0.6974 & 1 \\
B10 & 0.1929 & 10 & 0.3911 & 10 \\
B11 & -0.0035 & 11 & 0.2320 & 11 \\
\hline
\end{tabular}

Table 5. Ranking of benefits from diversity management in enterprises in Hungary

\begin{tabular}{ccccc}
\hline Benefit & $\begin{array}{c}\text { GDM2- } \\
\text { HSM }\end{array}$ & Rank & $\begin{array}{c}\text { GDM2- } \\
\text { TOPSIS }\end{array}$ & Rank \\
\hline B1 & 0.2896 & 7 & 0.5813 & 7 \\
B2 & 0.1920 & 10 & 0.4860 & 10 \\
B3 & 0.5499 & 1 & 0.7283 & 1 \\
B4 & 0.2478 & 9 & 0.5552 & 8 \\
B5 & 0.3573 & 6 & 0.5996 & 5 \\
B6 & 0.3706 & 5 & 0.5992 & 6 \\
B7 & 0.5473 & 2 & 0.7213 & 2 \\
B8 & 0.3822 & 4 & 0.6365 & 4 \\
B9 & -0.0420 & 11 & 0.3679 & 11 \\
B10 & 0.5115 & 3 & 0.6993 & 3 \\
B11 & 0.2563 & 8 & 0.5458 & 9 \\
\hline
\end{tabular}

Tau-Kendall's correlation coefficients for rankings of benefits from diversity management for each V4 country (see Table 6) as well as the visual representation of the distribution of values of GDM2HSM and GDM2-TOPSIS measures in the form of a box diagrams (see Figures 1-2) will be useful in analysing the results obtained from employing the GDM2-HSM and GDM2-TOPSIS methods. TauKendall's correlation coefficients enables the analysis of the relationship between two ordinal variables, therefore it is used, among others, in assessing the stability of rankings obtained with the use of MCDM methods.

Table 6. Tau-Kendall's correlation matrix for rankings of benefits from diversity management

\begin{tabular}{ccccc}
\hline & Poland & $\begin{array}{c}\text { Czech } \\
\text { Republic }\end{array}$ & Slovakia & Hungary \\
\hline Poland & 1 & - & - & - \\
Czech & 0.5273 & 1 & - & - \\
Republic & & & 1 & - \\
Slovakia & 0.4909 & 0.8182 & -0.0909 & 1 \\
Hungary & 0.1273 & 0.0182 & & \\
\hline
\end{tabular}



Figure 1. GDM2-HSM measures for the countries of the Visegrad

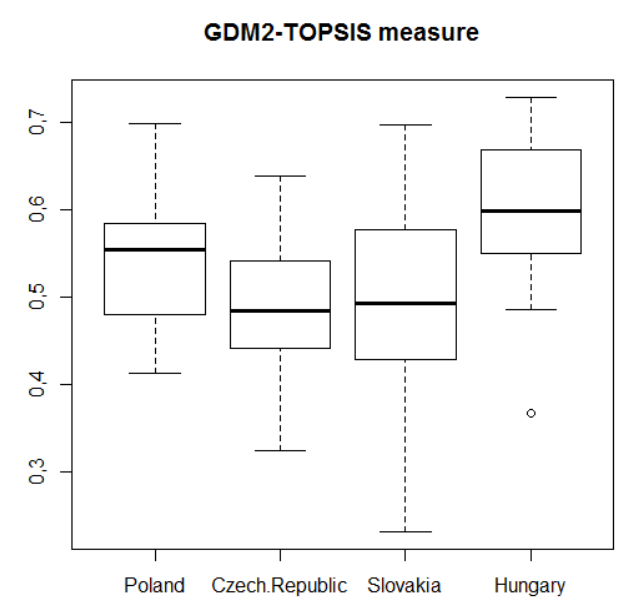




\section{Figure 2. GDM2-TOPSIS measures for the countries of the Visegrad}

It is easy notice that the values of the GDM2HSM measures are lower than the GDM2-TOPSIS measures. However, it did not affect the positions of the analyzed benefits in the obtained rankings, which proves the stability of the results obtained with the use of two methods. Slight differences were observed in the case of the results for Hungary, however, this did not affect the results of the correlation analysis between the rankings for individual countries.

The GDM2-HSM and GDM2-TOPSIS measures values presented in Tables 2-5 suggest that the participants of the survey were able to observe a relatively large impact of the implementation of the concept of diversity management on the majority of benefits obtained by organisations specified in the paper. However, an analysis of the correlation matrix clearly indicates that the opinions of representatives of organisations operating on the territory of Visegrad Group counties are strongly divided on the influence of diversity management on the specified benefits. The most compatible opinions have been observed among Czechs and Slovaks. Both have indicated, that diversity management most notably influences the obtained benefits in the area of mitigating the risk of discrimination at an organisation (B9) and the increase of creativity and innovativeness of teams (B8). They are both agreeable when it comes to indicating that diversity management has the least impact on achieving benefits in the form of cost reductions in inter alia employment, employee training (B11) and increasing the loyalty of clients (B10). Nonetheless, it has to be underscored that respondents from the Czech Republic have been more consequent in their evaluations (lower dispersion of the values of the GDM2-HSM and GDM2-TOPSIS measures seen in Figures 1-2) and have carried out a relatively lower assessment of the impact of diversity management on the benefits (as also seen in Figure 1).

The influence of diversity management on obtaining the benefits specified in the study has been most observed by respondents in Hungary. The values of the GDM2-HSM and GDM2-TOPSIS measures are higher for more benefits when compared to responses from other analysed countries. Moreover, taking into account the correlation indicators for Hungary presented in Table 6, large differences in the assessment of the influence of diversity management on obtaining benefits can be expected. As such, respondents have indicated that diversity management has the most impact on the level of employee satisfaction (B3). In the case of other countries this benefit is indicated somewhere in the middle of the ranking. The second most commonly indicated benefit was increase the retention of the most talented employees (B7) and in this case the evaluation is more consistent with responses in other countries. According to respondents from Hungary, diversity management has the lowest impact on mitigating the risk of discrimination at an organisation (B9), with which respondents from other V4 countries do not agree with.

The assessment of the concept of diversity management on the benefits for organisations specified in the study as evaluated by representatives of organisations based in Poland belong to one of the highest in the entire V4 group. Furthermore, the analysis of the scope of dispersion of answers (seen in Figure 1) also suggests that participants of the study from Poland tend to assess highly the influence of the concept of diversity management on the majority of the presented benefits. According to them, the concept in question to the largest degree contributes to the increase of creativity and innovativeness of teams (B8) and gaining new employees (B6). Whereas they have indicated cost reductions (B11) and increasing the loyalty of clients (B10) lowest in the ranking.

\section{Discussion}

The location of V4 countries in Central Europe sets them up as attractive places of business for industry, services and logistics [19]. The relatively favourable relation of labour costs to quality is still being maintained. However, the current demographic situation, an aging population, a low child birth rate and an outflow of V4 citizens to western Europe presents new challenges for the labour market. Deficiencies in the pool of domestic employees have become a fact, which puts pressure on enterprises to seek employees from outside V4 countries and the European Union. Organisations from V4 countries have to face an increasingly more culturally and generationally diverse teams of employees, which in turn presents new challenges for managers.

Socio-economic practise and other research does however show that the topic of diversity management in V4 countries and the benefits stemming from it is limited to the sphere of theoretical discourse $[8,9,36]$. Organisations from V4 countries are only starting to discover the potential, which is hidden in diversified human resources, meanwhile current deficiencies of employees can be partially satisfied with utilizing these hidden resources (for instance those of different age groups) and their potential.

More specifically, the research results presented in the article have shown the strongly diversified perceptions of benefits stemming from the 
implementation of the concept of diversity management in organisations of member states of the V4 group. The most consistent in their responses have been representatives from the Czech Republic and Slovakia, who have indicated as the most important benefit the mitigation of risk of discrimination at an organisation and increased creativity and innovation through building diverse teams. As the less important benefit they shown the cost reduction (acquisition, training, employment, employee replacements) and increased customer loyalty/retention of existing clients. The Czech Republic and Slovakia similarly assessed the importance of the individual benefits. The most dispersed responses have been given by representatives of organisations in Hungary, as they have indicated "the mitigation of risk of discrimination at an organisation" to be the least important, whereas they have indicated the level of employee satisfaction and increased customer loyalty/retention of existing clients as the most important. However, despite the different indications it has to be underscored that it was in Hungary where the influence of the concept of diversity management on the specified in the study benefits for organisations have been most appreciated.

On the other hand, representatives from Poland have indicated as the most important benefits the increased creativity and innovation through building diverse teams and acquiring the best employee. As the least significant benefit they indicated - cost reduction (acquisition, training, employment, employee replacements) and increased customer loyalty / retention of existing clients (same as the Czech Republic and Slovakia). Identifying the benefits of diversity in the workplace is an important stage in implementing the concept of diversity management in enterprises. Research confirms that perceived effects of implementing concept of diversity in the workplace in organizations on diverse may differ between countries.

Moreover, all of the countries surveyed do not fully appreciate the benefits of diversity in the workplace. Or they are not aware of these benefits, as evidenced by relatively low values of the estimated synthetic measures. This confirms that there is still a need to promote and disseminate the concept of diversity in the workplace in the organization and the benefits that result from it for the organization. Relatively low values of estimated synthetic measures indicate an underestimation of the benefits of diversity in the workplace in the organization in the Visegrad Group countries.

Therefore considering potential benefits resulting from implementation of the concept of diversity in the workplace in organization functioning in the area of Visegrad Group countries is a great opportunity of using a human capital and increasing the competitive advantage of that region in a globalized economy.

\section{Conclusion}

This study enriches the literature on diversity management and human resource management including diverse workforce management. It explores the phenomenon of diversity management in organizations and compares it in Visegrad Group countries. The aim has been to understand in depth what benefits of implementing the concept of diversity management in the organization indicate organizations in individual V4 countries and what importance do they attribute to particular benefits. Understanding the data underlying entrepreneur/managers behavior may help human resources management's to better manage knowledge on their employees, including its creation and performance processes. This should qualitatively transform the collected data into useful knowledge for managers and make it possible to improve the performance of their organization. In other words, collecting information about benefits of diversity management may allow organizations to generate new operational knowledge, which this may manage and further apply in strategic management [27, 38]. For this purpose, we have simultaneously measured opinions managers on how organizations individual benefits of diversity management and their ratings of those benefits.

This paper contributes to the diversity management literature by illustrating the importance of understanding the role of diversity management in organization's strategic management. Such influence is especially important for building competitive advantages in the V4 countries.

For firms' management, findings of this paper remind them that building diverse workforce build their competitive advantages consciously. For academia, this paper's findings cast light on role of workforce diversity in organization management and give a call for further research on the role of diversity management in organizations in Visegrad countries.

The practical implications of the findings are twofold. First, this study emphasizes the importance of management understanding of diversity management for successful organization Second, it stressed the broad array of benefits of diversity management in organization and managers lack of knowledge about it can lacking, impede the implementation of diversity management in organizations. To address this, organizations may want to look beyond data science to the required skills for understanding and engagement of diversity. 


\section{Limitations and Future Research}

In research priorities emerge, which pertain to diversity workplace in an organization, measuring it and its relationship with obtainable benefits at organizations, aimed at building an increasingly more fluent justification for the actions undertaken in this area. The society changes rapidly and demographic changes taking place in the world at large and in Europe (including V4) can potentially influence multiple aspects of managing organisations. Hence, organisations are increasingly characterised by diversity, both in terms of their external and internal surroundings. Another research direction for science, as well as for practitioners, is building awareness of the concept of diversity in the workplace and its role in managing organizations. Generally, modern organisations today, have to face challenges such as globalisation, competition and changes on the labour market. This paper is not without limitations. One limitation is regarding the selection of local organizations. Future research may include more organizations and additional industries. Another future research direction is the development of the issues of barriers related to diversity management and their correlation with benefits.

\section{References}

[1] Assessing Diversity Impact in Business. By the European Union Platform of Diversity Charters. (2013). European Union.

[2] Bell M.T. (2007), Diversity in Organizations, SOUTH-WESTERN CENGAGE Learning.

[3] Brief, A. P. (2008). Diversity at Work, Cambridge Companions to Management, New York: Cambridge University Press.

[4] Cox T. (1993) Cultural diversity in Organizations: Theory, Research, and practice, San Francisco: Berrett-Koehler Publisher.

[5] Diversity in organizations: Where are we now and where are we going? Human Resource Management Review, 19, pp. 117-33.

[6] Diversity Matters. (2014). McKinsey\&Company.

[7] Egan, M. L., Bendick, M., Jr. (2008). Combining multicultural management and diversity into one course on cultural competence. Academy of Management Learning \& Education, 7(3), pp. 387393.

[8] Eger, L., Indruchová, . (2014). Diversity Management - Perceptions And Attitudes By Czech Managers, E + M Ekonomie, Vol. 2014 Issue 1, pp. 73-81.

[9] Egerovà, D., Jirincovâ, M., Lancaric, D., Savov, R. (2013). Applying The Concept Of Diversity
Management In Organisations In The Czech Republic And The Slovak Republic - A Research Survey, Technological \& Economic Development of Economy, Vol. 19 Issue 2, pp. 350-366.

[10] Ely, R. J. and Thomas, D. A. (2001). Cultural diversity at work: The effects of diversity perspectives on work group processes and outcomes. Administrative Science Quarterly, 46(2), pp. 229-73.

[11] Espinoza, M. (2007). Turning diversity into a competitive advantage. Financial Executive, 23 (3), pp. 43-46.

[12] Gardenswartz, L., Rowe, A. (1998). Why diversity matters. HR Focus, 75(7), pp. 51-54.

[13] Gibbs, K., Han A., Lun J. (2000). Demographic Diversity in Teams: The Challenges, Benefits, and Management Strategies, Strategies for Team Science Success, pp. 197-205.

[14] Greco, S., Ehrgott, M., Figueira, J.R. (eds.). (2016). Multiple Criteria Decision Anaysis. State of the Art Surveys. Springer-Verlag. New York.

[15] Gross-Gołacka E. (2018). Zarządzanie różnorodnością. W kierunku zróżnicowanych zasobów ludzkich $w$ organizacji, Difin, Warszawa.

[16] Gross-Gołacka, E. (2016). Rola koncepcji zarządzania różnorodnością w doskonaleniu organizacji. Problemy Jakości, 4.

[17] Hellwig, Z. (1967). Procedure of Evaluating high Level Manpower Data and Typology of Countries by Means of the Taxonomic Method. COM/WS/91. Warsaw (unpublished UNESCO working paper).

[18] Hwang, C.L., Yoon, K. (1981). Multiple Attribute Decision Making. Methods and Applications. A State-of-the-Art Survey. New York. SpringerVerlag.

[19] Jedlička J., Kotian J., Münz R. (2014). Visegrad Four - 10 years of EU membership. Erste Group Research CEE Special Report.

[20] Jefmański, B., Sagan, A. (2021). Item Response Theory Models for the Fuzzy TOPSIS in the Analysis of Survey Data, Symmetry, 13, 223, pp. $1-28$.

[21] Kandola R., Fullerton J. (1998). Managing the Mosaic: Diversity in Action, 2nd edition, Institute of Personnel and Development.

[22] Kandola, R., Fullerton, J. (1994). Managing the mosaic-diversity in action, Cromwell Press, Wiltshire,

[23] Kaur R., Kaur G., Sahay U., Saini U. (2020). A Study of Diversity Management in Different Companies and Different Sectors, International Journal of Advanced Science and Technology, Vol. 29, No. 3, pp. 284-30.

[24] Kemper, L. E., Bader, A. K., Froese, F. J. (2016). Diversity management in ageing societies: A comparative study of Germany and Japan. Management Revue, 27(1/2), pp. 29-49.

[25] Kinicki A., Kreitner R. (2006). Organizational Behavior: Key Concepts, Skills And Best Practices, Irwin/McGraw-Hill; 2nd Edition. 
[26] Kirton G., Green A. (2005). The Dynamics of managing Diversity. A Critical Approach, Elsevier.

[27] Köllen T. (2019). Diversity Management: A Critical Review and Agenda for the Future, Journal of Management Inquiry Volume: 30 issue: 3, pp. 259-272.

[28] Liff S. (1996). Two routes to managing diversity: individual differences or social group characteristics, Employee Relations, 19(1), pp. 1126.

[29] Liff S. (1999). Diversity and equal opportunities: room for a constructive compromise?, Human Resource Management Journal, 9(1), pp. 65-75.

[30] Lingner, I., Nalbandian, J., \& Llorens,J. J. (2018). Public personnel management : Context and Strategies (Seventh). Routledge. pp. 155-178.

[31] Lockwood, N. R. 2005. Workplace diversity: Leveraging the power of difference for competitive advantage. HR Magazine, 50(6), pp. 1-10.

[32] Loden, M., Rosener J.B. (1991). Workforce America! Managing Employee Diversity as a Vital Resource, Illinois: Business One Irwin.

[33] Lorbiecki A., Jack G. (2000). Critical Turns in the Evolution of Diversity Management, British Journal of Management, 17, pp. 17-31.

[34] Managing diversity. Linking theory and practice to business performance. (2005). Chartered Institute of Personnel and Development, London.

[35] Methods and Indicators to Measure the CostEffectiveness of Diversity Policies in Enterprises Final Report. (2003). Centre for Strategy \& Evaluation Services 2003, pp. 20-40.

[36] Michalicka, T., Lancaric, D., Zach, H. (2021). Adopting the Diversity Management Approach. Case of Slovakia SHS Web of Conferences; Les Ulis, Vol. 92.

[37] Monks, K. (2007). The business impact of equality and diversity. Dublin: The international evidence. Equality Research Series The Equality Authority i National Centre for Partnership and Performance.

[38] Mor Barak, M. E. (2017). Managing diversity: Toward a globally inclusive work place (4th ed.) Thousand Oaks, CA: SAGE.

[39] Norton, J. R., Fox, R. E. (1997). The change equation: Capitalizing on diversity for effective organizational change. American Psychological Association.

[40] O'Donovan, D. Inclusion: Diversity Management 2.0. In: Managing Organizational Diversity, Trends and Challenges in Management and Engineering (ed. Machado C., Davim, J.P.), Springer International Publishing AG 2017, pp. 1-28.

[41] Özbilgin, M.F., Tatli A. 2008. Global Diversity Management: an evidence-based approach, Palgrave Macmillan, Basingstoke.

[42] Pocztowski, A. (2015). Zarządzanie zasobami ludzkimi na rynkach międzynarodowych. Wolters Kluwer business, Warszawa.
[43] Prasad, P., Mills, A. J. (1997). Understanding the dilemmas of managing workplace diversity. In P. Prasad, A. J. Mills, M. Elmes, A. Prasad (Eds.), Managing the organizational melting pot: Dilemmas of workplace diversity, ThousandOaks, CA: Sage, pp. 3-27.

[44] Robinson, G., Dechant, K. (1997). Building a business case for diversity. Academy of Management Executive, 11(3), pp. 21-31.

[45] Salih, M.M., Zaidan, B.B., Zaidan, A.A., Ahmed, M.A. (2019). Survey on fuzzy TOPSIS state-ofthe-art between 2007 and 2017, „Computers \& Operations Research", vol. 104, pp. 207-227.

[46] Shore, L. M., Chung-Herrera, B. G., Dean, M. A., Ehrhart, K. H., Jung, D. I., Randel, A. E., Singh, G. (2009). Diversity in organizations: Where are we now and where are we going? Human Resource Management Review, 19(2), pp. 117-133.

[47] Simo, P, \& Sallan, J.M. (2009). Intangible Capital: An opportunity for $\mathrm{PhD}$ students and junior researchers. Intangible Capital, 5(3), pp. 227-234.

[48] Skrzypek, E.(2009). Kapitał ludzki i jego wpływ na jakość. Outsourcing. Kraków.

[49] Sonnenschein, W. (1997). The Diversity Toolkit. How You Can Build and Benefit from a Diverse Workforce, McGraw-Hill Companies, New York.

[50] Syed, J., Özbilgin, M. (2009). A relational framework for international transfer of diversity management practices. The International Journal of Human Resource Management, 20, pp. 2435-2453.

[51] The costs and benefits of diversity. A Study on Methods and Indicators to Measure the CostEffectiveness of Diversity Policies in Enterprises of Diversity Policies in Enterprises. (2003). European Commission, October.

[52] Thomas, R. (1990). From affirmative action to affirming diversity. Harvard Business Review, 107-117.

[53] Thomas, R.R. Jr. (1991). Beyond race and gender. Unleashing the power of your total work force by managing diversity, New York: Amacom.

[54] Thomas, R.R. Jr. (1999). Building a House for Diversity, New York: Amacom.

[55] Tipper, J. (2004). How to increase diversity through your recruitment practices. Industrial and Commercial Training, 36(4), pp. 158-161.

[56] Velinov, E.(2018). Diversity Management Globalization in Central and Eastern Europe: The Case of Pharmaceutical Industry, European Research Studies Journal Volume XXI, Issue 1, pp. $82-89$.

[57] Walesiak, M. (1999). Distance measure for ordinal data. Argumenta Oeconomica, 2(8).

[58]Zavadskas, E.K., Turskis, Z., Kildiene, S. (2014). State of art surveys of overviews on MCDM/MADM methods, Technological and Economic Development of Economy, 20(1), pp. 165-179. 